\title{
BREEDING STRUCTURE OF THE SAND FLY LUTZOMYIA LONGIPALPIS (LUTZ \& NEIVA) IN BRAZIL
}

\begin{abstract}
JOHN-PAUL MUTEBI, BRUCE ALEXANDER, ITALO SHERLOCK, JOSE WELLINGTON, ADELSON A. SOUZA, JEFFREY SHAW, ELIZABETH F. RANGEL, AND GREGORY C. LANZARO

Center for Tropical Diseases, Department of Pathology, University of Texas Medical Branch, Galveston, Texas; Departmento de Parasitologia, Instituto de Ciências Biológicas, Universidade Federal de Minas Gerais, Belo Horizonte, Minas Gerais, Brazil; Centro de Pesquisas Gonçalo Moniz-FIOCRUZ, Salvador, Bahia, Brazil; Núcleo de Medicina Tropical, Universidade Federal do Ceará, Fortaleza, Ceará, Brazil; Seção de Parasitologia, Instituto Evandro Chagas, Fundação Serviços Pública, Belém, Pará, Brazil; Departamento de Parasitologia, Instituto de Ciências Biomédicas, Universidade de São Paulo, São Paulo, São Paulo, Brazil; Departmento de Entomologia, Instituto Oswaldo Cruz, Rio de Janeiro, Brazil
\end{abstract}

\begin{abstract}
Eleven populations of Lutzomyia longipalpis (Lutz \& Neiva), the sand fly vector of Leishmania chagasi, from different areas of Brazil were analyzed for genetic variation at 16 enzyme loci. In this region, the prevalence of visceral leishmaniasis (VL) caused by $L$. chagasi is spotty and reproductive isolation among populations of $L u$. longipalpis has been reported. It is thought that morphologically similar cryptic species with varying vectorial capacity may be responsible for the discontinuous distribution of VL. The aim was to study the genetic structure of populations within this region and to identify demes that may represent sibling species. Genotypic frequencies within populations were in close compliance to Hardy-Weinberg expectations, suggesting there are no sympatric species among these 11 populations. Levels of genetic distance between pairs of populations were very low $(<0.03)$, consistent with local populations within a single sand fly species. When genotypic frequency data for all populations were pooled, 9 of the 13 polymorphic loci deviated from Hardy-Weinberg expectations, indicating some degree of genetic substructuring. Estimates of effective migration rates $\left(N_{e} m\right)$ among all populations were low, 2.73, suggesting that gene flow is restricted among populations, which is probably the reason for the observed genetic substructuring.
\end{abstract}

Sand flies in the Lutzomyia longipalpis (Lutz \& Neiva) species complex ${ }^{1-3}$ are the major vectors of Leishmania chagasi Cunha \& Chagas, the etiologic agent for visceral leishmaniasis (VL) in Latin America. ${ }^{4-7}$ In this region, VL causes more than 16,000 new clinical infections annually and fatalities are common especially among children. More than 90\% of the VL cases reported from Latin America are in Brazil. $^{8}$ In Brazil, VL is endemic in the northeastern part of the country, particularly in the states of Bahia, Piauí, Maranhão, and Ceará, ${ }^{9-11}$ and in the southeastern region. ${ }^{12}$ There is a great deal of variation in number of cases reported and the epidemiology of VL in different parts of Brazil. In Pará in the lower Amazon basin, VL cases are sporadic ${ }^{5,13}$ whereas in Bahia, epidemic outbreaks, each lasting about three years, are recorded every decade. ${ }^{14}$ The reported number of cases is increasing. Eduado de Alencar ${ }^{10}$ reported only 2,490 clinical cases in the seven-year period between 1953 and 1960, whereas 9,295 cases of VL were reported between 1983 and 1988. ${ }^{11}$ Recently, Momen ${ }^{15}$ reported that more than 3,000 new cases were diagnosed in 1994 alone. Furthermore, VL has traditionally been a rural disease, but the number of urban cases reported is steadily increasing. ${ }^{16}$

In the past 10 years the number of studies of the biology and genetics of the phlebotomine sand fly Lu. longipalpis has increased tremendously. We now know that this sand fly is a complex of three and possibly more sibling species. ${ }^{1,2}$ The initial cross-mating studies were done by Ward and others $^{2}$ among laboratory strains collected from Brazil. They found insemination failure in attempted crosses between several strains and these were associated with differences in chemical composition of male pheromones, ${ }^{17,18}$ suggesting the presence of pre-zygotic reproductive barriers. Since then, other investigators such as Lanzaro and others ${ }^{1}$ have reported reproductive isolation and significant genetic divergence among strains from different geographic regions. They also reported abnormal sperm produced by intercolony $\mathrm{F}_{1}$ hybrid males, indicating the presence of post-zygotic reproductive barriers. Recently, Yin and others ${ }^{19}$ have reported karyotype differences in metaphase chromosomes of laboratory reared sand flies from four populations: El Callejon (Colombia), Liberia (Costa Rica), Jacobina and Lapinha Caves (Brazil). They found that the position of the centromere on the smallest chromosome (chromosome 4) was different in some strains. They also described distinct G-banding patterns for each of the strains. This complicates the taxonomic status of Brazilian Lu. longipalpis. Flies from Jacobina, Bahia, and Lapinha Caves, Minas Gerais are thought to be reproductively compatible because males from these localities produce pheromones of the same chemical composition based on the terpenoids farnesene and homofarnesene. ${ }^{3}$

The morphologic differences first described by Mangabeira in $1969^{3}$ were found to be intra-specific polymorphisms. ${ }^{3,20}$ The characters are pairs of pale spots on the third and fourth abdominal tergites of male flies. Some populations have a single pair on the fourth abdominal tergite, whereas others have one pair each on the third and fourth tergites. Intermediate forms have been observed both in laboratory crosses ${ }^{3}$ and in the field. ${ }^{20}$ Furthermore, reproductive isolation and pheromones of different chemical composition have been reported among populations with the same spot morphology, indicating that this character is not species specific. Moreover, abdominal spots can only be used to differentiate males.

Isozyme analysis has been used extensively in systematics and population genetic analysis of phlebotomine sand flies. Caillard and others ${ }^{21}$ compared two cryptic species, Lu. (Psychopopygus) carrerai and Lu. (Psychopopygus) yucumensis, and found two diagnostic isozyme loci and three other loci that provided evidence of reproductive isolation. Rogo and others $^{22}$ used isozymes to distinguish Phlebotomus pedifer, a vector of $L$. aethiopica, the causative agent of cutaneous leishmaniasis in Kenya and Ethiopia, and Ph. elegonensis, a 


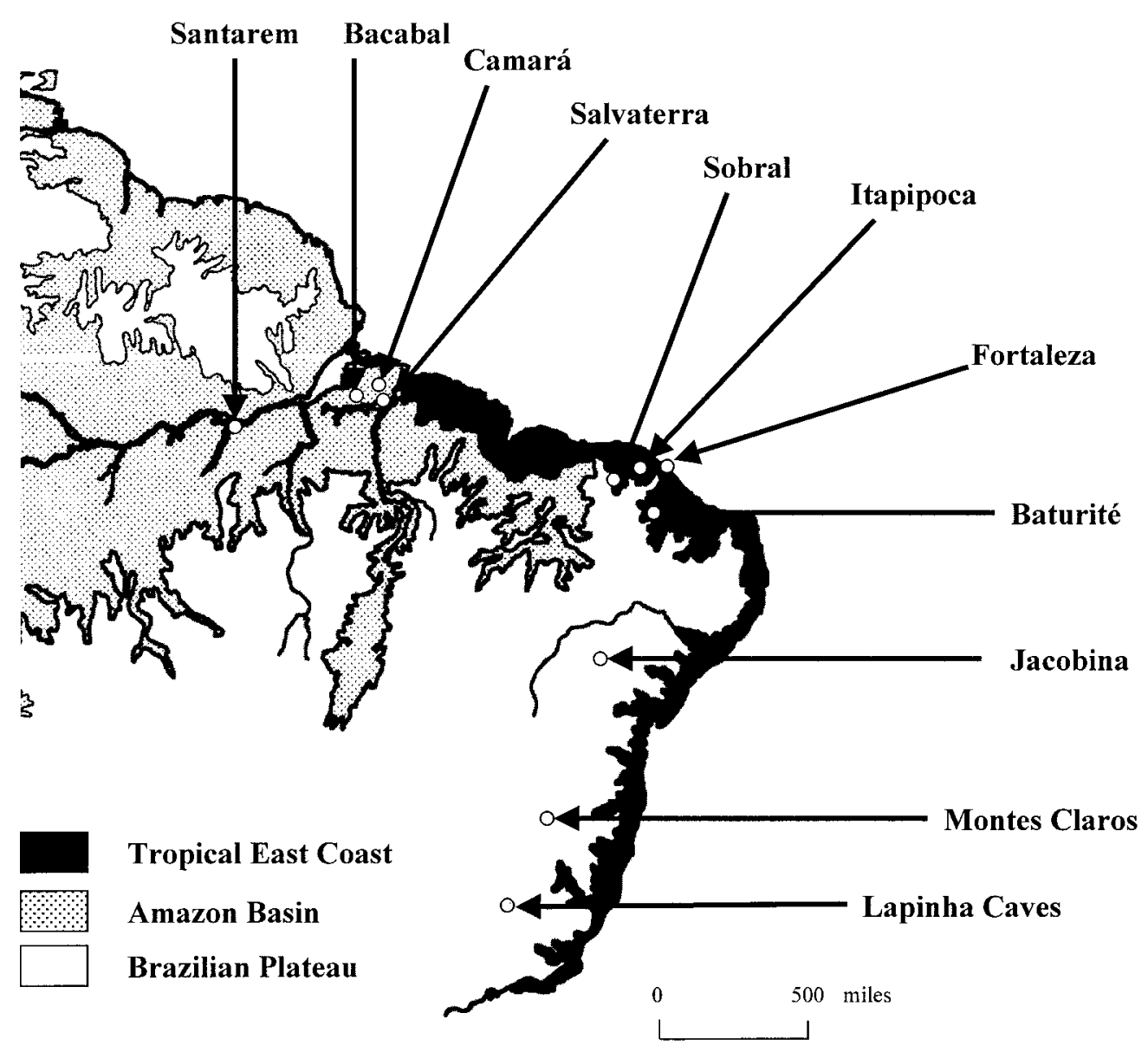

FIGURE 1. Collection sites in Brazil.

non-vector that is morphologically very similar. Kreutzer and others ${ }^{23}$ used isozyme data to identify populations of Lutzomyia species in the Lu. verrucarum group, which includes vectors of Bartonella bacilliformis and Leishmania species in the neotropics. Perrotti and others ${ }^{24}$ found that the isocitrate dehydrogenase and the leucine aminopeptidase-1 loci were useful for distinguishing $P h$. perniciosus and $P h$. perfiliewi, the vectors of $L$. infantum in southern Italy.

Isozyme analysis has been applied to a number of laboratory and field populations of $\mathrm{Lu}$. longipalpis. Bonnefoy and others ${ }^{25}$ studied populations in the Yungas, Bolivia and found them to be genetically homogeneous. They found low levels of genetic variability and attributed it to a founder effect. Dujardin and others ${ }^{26}$ found relatively large genetic distances between one spot and two spot populations in Bolivia, but very low genetic divergence between two one spot populations. Lanzaro and others ${ }^{1}$ studied isozyme variation among three populations from Colombia, Costa Rica, and Brazil. They also found that hybridization of these populations resulted in sterile males in the $\mathrm{F}_{1}$ generation. They concluded that isozyme differences between populations are maintained by reproductive isolation and that these therefore represent different species. Recently, isozyme surveys of field populations have been conducted in Colombia, Central America, and Brazil. Munstermann and others ${ }^{27}$ and Lanzaro and others ${ }^{28}$ found very low genetic variability and little divergence among field populations in Colombia, consistent with local populations within the same species. Similarly, Mutebi and others ${ }^{29}$ found very low genetic variability and little divergence among 11 populations from three countries in Central America: Honduras, Costa Rica, and Nicaragua. Recently, Mukhopadhyay and others ${ }^{20}$ reported little genetic divergence among three allopatric populations in Brazil (Jacobina, Lapinha Caves, and Natal), again suggesting that these populations are conspecific. They also reported genetic homogeneity among males of the two abdominal spot morphologic forms from Natal.

In this study, our aims were to study the breeding structure of allopatric Lu. longipalpis populations in Brazil. We used a population genetics approach and isozymes as genetic markers. We analyzed 11 populations representing most of the distribution of Lu. longipalpis in Brazil.

\section{MATERIALS AND METHODS}

Sand fly populations. Adult flies from 11 natural populations of $\mathrm{Lu}$. longipalpis in Brazil were collected from 3 climatic regions; the Amazon basin, the Brazilian plateau, and the tropical east coast. (Figure 1). The climate in the Amazon basin is equatorial with annual rainfall of more than 60 inches and an average daily temperature range of 22$32^{\circ} \mathrm{C}$. In the Brazilian plateau, annual rainfall is $50-60$ inches, average daily temperature ranges from $13^{\circ} \mathrm{C}$ to $34^{\circ} \mathrm{C}$, and there are distinct wet and dry seasons. The tropical east coast 
TABLE 1

Enzyme loci

\begin{tabular}{|c|c|c|c|}
\hline Enzyme & E.C. no.* ${ }^{*}$ & Abbreviation & Buffer $\dagger$ \\
\hline 1 Aconitate hydratase- 2 & 4.4.1.3 & Acon-2 & CA-7 \\
\hline 2 Aldehyde dehydrogenase & 1.2.1.3 & Aldh & $\mathrm{C}$ \\
\hline 3 Fumarate hydratase & 4.41 .2 & Fum & TBE \\
\hline $\begin{array}{l}4 \alpha \text {-Glycerol-3-phosphate } \\
\text { dehydrogenase }\end{array}$ & 1.1 .1 .8 & $\alpha-G p d$ & CA-7 \\
\hline 5 Aspartate transminase- 1 & 2.6.1.1 & Aat-1 & CA-7 \\
\hline 6 Aspartate transminase- 2 & 2.6.1.1 & Aat-2 & CA-7 \\
\hline $\begin{array}{l}7 \text { Glyceraldehyde-3-phosphate } \\
\text { dehydrogenase }\end{array}$ & 1.2.1.12 & G3pdh & CA-7 \\
\hline 8 Hexokinase & 2.7.1.1 & $H k$ & TBE \\
\hline 9 Isocitrate dehydrogenase- 1 & 1.1.1.42 & $I d h-1$ & $\mathrm{C}$ \\
\hline 10 Isocitrate dehydrogenase- 2 & 1.1.1.42 & $I d h-2$ & $\mathrm{C}$ \\
\hline 11 Malate dehydrogenase-1 & 1.1.1.37 & $M d h-1$ & $\mathrm{C}$ \\
\hline 12 Malic acid dehydrogenase- 2 & 1.1.1.37 & $M d h-2$ & $\mathrm{C}$ \\
\hline 13 Malic enzyme-1 & 1.1 .1 .40 & $M e-1$ & $\mathrm{C}$ \\
\hline 14 glucosephosphate isomerase & 5.3 .1 .9 & Gpi & TBE \\
\hline 15 Phosphoglucomutase & 2.7.5.1 & Pgm & TBE \\
\hline $16 \alpha, \alpha$-Trehalase & 3.2.1.28 & Tre & CA-7 \\
\hline
\end{tabular}

$*$ E.C. $=$ Enzyme Commission

$\dagger$ CA-7: gel buffer $=0.009 \mathrm{M}$ Tris, $0.003 \mathrm{M}$ citric acid, $\mathrm{pH} 7.0$ (undiluted), electrode buffer $=0.135 \mathrm{M}$ Tris, $0.04 \mathrm{M}$ citric acid, $\mathrm{pH} 7.0$ (undiluted) (Ayala and others ${ }^{32}$ ); $\mathrm{C}:$ ge buffer $=0.002 \mathrm{M}$ citric acid, $\mathrm{pH} 6.0$ (undiluted), electrode buffer $=0.04 \mathrm{M}$ citric acid, $\mathrm{pH}$ 6.1 (undiluted) ( $\mathrm{pH}$ for buffer $\mathrm{C}$ is adjusted with $\mathrm{N}$-(3-aminopropyl)-morpholine) (Clayton and Tretiak ${ }^{31}$ ): TBE. $0.1 \mathrm{M}$ Tris, $0.05 \mathrm{M}$ boric acid, $0.002 \mathrm{M}$ EDTA, $\mathrm{pH} 8.6$ (undiluted) (gel and electrode buffer identical) (Selander and others ${ }^{30}$ ).

extends from the mouth of the Amazon River to Rio de Janeiro and has a hot, tropical climate. Collections were taken from domestic animal using either mouth aspirators or in Centers for Disease Control (CDC) (Atlanta, GA) light traps. The CDC light traps were used in the Amazon basin (Salvaterra, Santarem, Camará, and Bacabal) and approximately $1,000 \mathrm{Lu}$. longipalpis were captured overnight in each trap. Mouth aspirators were used in the Brazilian plateau (Lapinha Caves, Jacobina, Montes Claros) and the tropical east coast (Fortaleza, Baturité, Sobral, Itapipoca) because very few flies entered CDC light traps in these regions. Five populations were from the northeastern states of Ceará (Fortaleza, Baturité, Sobral and Itapipoca) and Bahia (Jacobina), which are endemic for VL. The other populations were from states with low VL incidence; Pará (Salvaterra, Santarem, Camará and Bacabal) and Minas Gerais (Lapinha Caves and Montes Claros). Field-collected sand flies were identified to species using standard morphologic characteristics ${ }^{7}$ and transported to the laboratory in liquid nitrogen. In the laboratory, they were stored at $-80^{\circ} \mathrm{C}$ until used in isozyme assays.

Isozyme assays. Sand flies were assayed for genetic variation at 16 isozyme loci by starch gel electrophoresis. ${ }^{30}$ Sand flies were homogenized individually in $8 \mu$ l of distilled water using a micropipette tip. The homogenate was fractionated by electrophoresis on $12.5 \%(\mathrm{w} / \mathrm{v})$ horizontal starch gels. Three buffer systems, Ayala C (CA-7), C, and TBE (Table 1), were used to maximize electrophoretic separation and to improve visualization of histochemically stained products. The 16 enzymes assayed are listed in Table 1. Bands within staining regions were assumed to be controlled by a single gene. Differences in migration distances of bands at the same locus were designated as different alleles, and multiple bands at the same locus in an individual were assumed to be heterozygous. Loci were designated with positive or negative codes depending on whether they migrated to the anode or to the cathode, respectively. Sand fly samples from three laboratory stocks, Melgar (Colombia), Liberia, (Costa Rica), and Lapinha Caves (Brazil), used by Lanzaro and others ${ }^{1}$ were included on each gel to help with identification of the alleles. This system was initiated to allow direct comparison of data from different studies to those of Lanzaro and others, ${ }^{1}$ Lanzaro and others, ${ }^{28}$ Mutebi and others, ${ }^{29}$ and of future studies.

Data analysis. Genotypes of individuals were organized into text input files and populations were analyzed for genetic variability, compliance to Hardy-Weinberg $(\mathrm{H}-\mathrm{W})$ expectations, and for genetic relatedness using a FORTRAN77 computer program BIOSYS $-1 .^{33}$ The effective migration rates $\left(N_{e} m\right)$ were calculated from the equation $N_{e} m=(1-$ $\left.\mathrm{F}_{\mathrm{ST}}\right) / 4 \mathrm{~F}_{\mathrm{ST}} \cdot{ }^{34}$

\section{RESULTS}

Genetic variability. Gene frequency data associated with each allelic variant are summarized in Table 2 . The percentage of polymorphic loci varied from $6.3 \%$ in Bacabal to $50 \%$ in Lapinha Caves (Table 3). Taking all populations into account, 10 of the 16 enzyme loci were polymorphic (Table 2 ). To determine genetic variation within individual populations, average heterozygosity $(H)$ values were calculated assuming that populations were in $\mathrm{H}-\mathrm{W}$ equilibrium. Estimated values for expected $H$ together with average numbers of alleles per locus and percentage of polymorphic loci in each population are presented in Table 3. Heterozygosities were low for populations on Marajo island (Salvaterra = $4.5 \%$, Bacabal $=5.2 \%$, and Camará $=6.1 \%$ ) at the mouth of the Amazon River (Pará). In the northeastern state of Ceará, heterozygosities were moderately high $($ Fortaleza $=$ $8.2 \%$, Itapipoca $=8.9 \%$, Sobral $=9.8 \%$, and Baturité $=$ $11.1 \%$ ), and for the more southern populations, heterozygosities were $11.7 \%$ in Jacobina, Bahia and $16.3 \%$ and $12.4 \%$ in Lapinha Caves and Montes Claros, respectively. Heterozygosity in Santarem, deep in the Amazon basin, was $12.4 \%$

Breeding structure. To determine if mating is random within single populations, genotype frequencies for all polymorphic loci were tested for goodness of fit to H-W equilibrium. At loci with more than 2 alleles, genotypes were pooled considering all alleles except the most common one as a single allele. This was done because the chi-square test is problematic when the expected frequencies of some classes are low. Only minor deviations were observed and these may be attributed to sampling errors. Genotypic frequency data for all populations were pooled and tested for compliance to $\mathrm{H}-\mathrm{W}$ equilibrium. Frequencies of genotypes at 9 of the 13 polymorphic loci differed significantly from $\mathrm{H}-\mathrm{W}$ expectations, suggesting some degree of genetic substructuring among populations.

Genetic differentiation. Genetic differentiation among populations was quantified using Wright's $\mathrm{F}_{\mathrm{ST}}$ statistic. The calculated $\mathrm{F}_{\mathrm{ST}}$ was low (0.084, Table 4$)$, but positive suggesting restricted gene flow among populations. Estimates of effective migration $\left(N_{e} m\right)$ for all 11 populations was low (2.73), indicating restricted migration and immigration among populations.

Genetic distance and similarity coefficients $\left(\mathrm{Nei}^{35}\right)$ showed low levels of genetic differentiation among populations. 
TABLE 2

Allele frequencies in 11 field populations of Lutzomyia longipalpis in Brazil

\begin{tabular}{|c|c|c|c|c|c|c|c|c|c|c|c|}
\hline \multirow[b]{2}{*}{ Locus $\dagger$} & \multicolumn{11}{|c|}{ Population* } \\
\hline & FTZ & SVT & LAP & SBR & JAC & CMR & BAT & BAC & ITA & MC & SAN \\
\hline \multicolumn{12}{|l|}{$M d h-1$} \\
\hline$(\mathrm{N})$ & 54 & 45 & 66 & 55 & 65 & 70 & 59 & 55 & 70 & 50 & 50 \\
\hline A & 0.85 & 1.00 & 0.77 & 0.87 & 0.95 & 0.98 & 0.92 & 0.96 & 0.94 & 0.68 & 0.74 \\
\hline B & 0.07 & 0 & 0.14 & 0.09 & 0.02 & 0.02 & 0.04 & 0 & 0.01 & 0.30 & 0.16 \\
\hline $\mathrm{C}$ & 0.07 & 0 & 0.10 & 0.03 & 0.02 & 0 & 0.03 & 0.04 & 0.04 & 0.02 & 0.06 \\
\hline $\mathrm{D}$ & 0.01 & 0 & 0 & 0 & 0.01 & 0 & 0 & 0 & 0 & 0 & 0 \\
\hline $\mathrm{F}$ & 0 & 0 & 0 & 0.01 & 0 & 0 & 0 & 0 & 0 & 0 & 0.02 \\
\hline G & 0 & 0 & 0 & 0 & 0 & 0 & 0 & 0 & 0 & 0 & 0.02 \\
\hline \multicolumn{12}{|l|}{$M d h-2$} \\
\hline$(\mathrm{N})$ & 75 & 65 & 76 & 80 & 76 & 80 & 59 & 70 & 80 & 65 & 65 \\
\hline A & 0.99 & 0.99 & 0.99 & 1.00 & 0.99 & 1.00 & 1.00 & 0.99 & 0.99 & 0.99 & 1.00 \\
\hline B & 0.01 & 0.01 & 0 & 0 & 0.01 & 0 & 0 & 0.01 & 0.01 & 0 & 0 \\
\hline $\mathrm{C}$ & 0 & 0 & 0.01 & 0 & 0 & 0 & 0 & 0 & 0 & 0.01 & 0 \\
\hline \multicolumn{12}{|l|}{$M e-1$} \\
\hline$(\mathrm{N})$ & 75 & 75 & 57 & 60 & 70 & 70 & 49 & 60 & 64 & 70 & 70 \\
\hline A & 0.97 & 0.98 & 0.98 & 0.98 & 0.99 & 0.94 & 0.94 & 0.98 & 1.00 & 1.00 & 0.99 \\
\hline B & 0.03 & 0.02 & 0.02 & 0.02 & 0.01 & 0.06 & 0.06 & 0.02 & 0 & 0 & 0.01 \\
\hline $\mathrm{C}$ & 0 & 0 & 0 & 0 & 0 & 0.01 & 0 & 0 & 0 & 0 & 0 \\
\hline \multicolumn{12}{|l|}{$I d h-1$} \\
\hline$(\mathrm{N})$ & 50 & 40 & 62 & 50 & 61 & 50 & 50 & 50 & 50 & 50 & 50 \\
\hline A & 0.98 & 1.00 & 0.90 & 0.99 & 0.97 & 0.99 & 1.00 & 0.98 & 1.00 & 0.86 & 0.99 \\
\hline B & 0.01 & 0 & 0.07 & 0 & 0.03 & 0.01 & 0 & 0.02 & 0 & 0.04 & 0 \\
\hline $\mathrm{C}$ & 0.01 & 0 & 0.01 & 0.01 & 0.01 & 0 & 0 & 0 & 0 & 0.10 & 0 \\
\hline $\mathrm{D}$ & 0 & 0 & 0.02 & 0 & 0 & 0 & 0 & 0 & 0 & 0.10 & 0.01 \\
\hline \multicolumn{12}{|l|}{$I d h-2$} \\
\hline$(\mathrm{N})$ & 40 & 40 & 37 & 40 & 32 & 40 & 40 & 40 & 40 & 50 & 50 \\
\hline A & 1.00 & 1.00 & 1.00 & 1.00 & 1.00 & 1.00 & 1.00 & 1.00 & 1.00 & 1.00 & 1.00 \\
\hline \multicolumn{12}{|l|}{ Aldh } \\
\hline$(\mathrm{N})$ & 50 & 60 & 64 & 50 & 52 & 30 & 51 & 68 & 35 & 55 & 45 \\
\hline A & 1.00 & 0.94 & 0.86 & 0.90 & 0.90 & 1.00 & 0.81 & 0.98 & 1.00 & 1.00 & 1.00 \\
\hline B & 0 & 0 & 0.08 & 0.10 & 0.06 & 0.00 & 0.12 & 0 & 0 & 0 & 0 \\
\hline C & 0 & 0.05 & 0.06 & 0 & 0.02 & 0 & 0.07 & 0.02 & 0 & 0 & 0 \\
\hline $\mathrm{D}$ & 0 & 0.01 & 0 & 0 & 0.02 & 0 & 0 & 0 & 0 & 0 & 0 \\
\hline \multicolumn{12}{|c|}{ Aat-1 (Got-1) } \\
\hline$(\mathrm{N})$ & 53 & 72 & 55 & 79 & 61 & 92 & 53 & 53 & 73 & 51 & 52 \\
\hline A & 0.25 & 0.21 & 0.11 & 0.25 & 0.02 & 0.24 & 0.32 & 0.23 & 0.24 & 0.11 & 0.39 \\
\hline B & 0 & 0.01 & 0.03 & 0.02 & 0 & 0.09 & 0.14 & 0.04 & 0.12 & 0 & 0 \\
\hline C & 0.75 & 0.76 & 0.86 & 0.71 & 0.97 & 0.66 & 0.52 & 0.73 & 0.63 & 0.89 & 0.62 \\
\hline $\mathrm{D}$ & 0 & 0.01 & 0 & 0.02 & 0.02 & 0.02 & 0.02 & 0 & 0.01 & 0 & 0 \\
\hline $\mathrm{F}$ & 0.01 & 0 & 0 & 0.01 & 0 & 0 & 0 & 0 & 0 & 0 & 0 \\
\hline G & 0 & 0.01 & 0 & 0 & 0 & 0 & 0 & 0.01 & 0 & 0 & 0 \\
\hline \multicolumn{12}{|l|}{ Aat-3 } \\
\hline$(\mathrm{N})$ & 50 & 55 & 41 & 65 & 49 & 65 & 37 & 55 & 65 & 45 & 35 \\
\hline A & 1.00 & 1.00 & 1.00 & 1.00 & 1.00 & 1.00 & 1.00 & 1.00 & 1.00 & 1.00 & 1.00 \\
\hline \multicolumn{12}{|l|}{ G3pdh } \\
\hline$(\mathrm{N})$ & 50 & 50 & 32 & 55 & 47 & 30 & 30 & 45 & 45 & 30 & 40 \\
\hline A & 1.00 & 1.00 & 1.00 & 1.00 & 1.00 & 1.00 & 1.00 & 1.00 & 1.00 & 1.00 & 1.00 \\
\hline \multicolumn{12}{|c|}{ Gpi (Pgi) } \\
\hline$(\mathrm{N})$ & 50 & 50 & 71 & 55 & 57 & 50 & 49 & 59 & 50 & 75 & 75 \\
\hline A & 0.01 & 0 & 0 & 0 & 0.02 & 0 & 0 & 0.02 & 0 & 0 & 0 \\
\hline B & 0.01 & 0 & 0 & 0.02 & 0.04 & 0 & 0.01 & 0 & 0.01 & 0.02 & 0.01 \\
\hline C & 0 & 0.01 & 0.02 & 0 & 0 & 0.02 & 0 & 0.03 & 0 & 0.04 & 0.01 \\
\hline D & 0 & 0 & 0 & 0 & 0 & 0 & 0 & 0 & 0.01 & 0.01 & 0.01 \\
\hline $\mathrm{F}$ & 0 & 0.01 & 0.01 & 0 & 0.02 & 0 & 0 & 0 & 0.01 & 0.01 & 0.01 \\
\hline $\mathrm{H}$ & 0 & 0 & 0.01 & 0 & 0 & 0 & 0 & 0 & 0 & 0 & 0 \\
\hline I & 0.98 & 0.98 & 0.96 & 0.98 & 0.93 & 0.98 & 0.99 & 0.96 & 0.97 & 0.93 & 0.95 \\
\hline$H k$ & & & & & & & & & & & \\
\hline$(\mathrm{N})$ & 70 & 70 & 62 & 77 & 57 & 70 & 60 & 70 & 60 & 80 & 66 \\
\hline A & 0.98 & 1.00 & 0.99 & 0.97 & 1.00 & 1.00 & 1.00 & 1.00 & 1.00 & 0.99 & 0.98 \\
\hline B & 0.02 & 1.00 & 0.01 & 0.01 & 0 & 0 & 0 & 0 & 0 & 0 & 0 \\
\hline C & 0 & 0 & 0 & 0.01 & 0 & 0 & 0 & 0 & 0 & 0.01 & 0.02 \\
\hline
\end{tabular}


TABLE 2

Continued

\begin{tabular}{|c|c|c|c|c|c|c|c|c|c|c|c|}
\hline \multirow[b]{2}{*}{ Locus $\dagger$} & \multicolumn{11}{|c|}{ Population* } \\
\hline & FTZ & SVT & LAP & SBR & JAC & CMR & BAT & BAC & ITA & MC & SAN \\
\hline \multicolumn{12}{|l|}{ Pgm } \\
\hline$(\mathrm{N})$ & 77 & 80 & 53 & 76 & 52 & 68 & 49 & 58 & 64 & 78 & 64 \\
\hline A & 0.90 & 1.00 & 0.50 & 0.67 & 0.30 & 0.98 & 0.83 & 0.98 & 0.73 & 0.62 & 0.61 \\
\hline B & 0.03 & 0 & 0.45 & 0.28 & 0.30 & 0.01 & 0.14 & 0.02 & 0.23 & 0.22 & 0.18 \\
\hline C & 0.07 & 0 & 0.05 & 0.03 & 0.04 & 0.02 & 0.03 & 0 & 0.01 & 0.07 & 0.18 \\
\hline $\mathrm{D}$ & 0 & 0 & 0 & 0.01 & 0.04 & 0 & 0 & 0 & 0 & 0.02 & 0 \\
\hline $\mathrm{E}$ & 0.01 & 0 & 0 & 0.01 & 0.30 & 0 & 0 & 0 & 0.03 & 0.02 & 0.01 \\
\hline $\mathrm{H}$ & 0 & 0 & 0 & 0 & 0 & 0 & 0 & 0 & 0 & 0.05 & 0.02 \\
\hline I & 0 & 0 & 0 & 0 & 0.01 & 0 & 0 & 0 & 0 & 0 & 0 \\
\hline $\mathrm{J}$ & 0 & 0 & 0 & 0 & 0.01 & 0 & 0 & 0 & 0 & 0 & 0 \\
\hline \multicolumn{12}{|l|}{ Fum } \\
\hline$(\mathrm{N})$ & 65 & 65 & 58 & 70 & 79 & 55 & 50 & 65 & 55 & 90 & 89 \\
\hline A & 0.86 & 0.93 & 0.87 & 0.96 & 0.89 & 0.89 & 0.88 & 0.96 & 0.83 & 0.87 & 0.82 \\
\hline B & 0.12 & 0.06 & 0.11 & 0.04 & 0.10 & 0.11 & 0.12 & 0.04 & 0.17 & 0.11 & 0.16 \\
\hline $\mathrm{C}$ & 0 & 0.01 & 0.02 & 0.00 & 0.01 & 0 & 0 & 0 & 0 & 0.02 & 0.03 \\
\hline $\mathrm{D}$ & 0.02 & 0 & 0 & 0 & 0 & 0 & 0 & 0 & 0 & 0 & 0 \\
\hline \multicolumn{12}{|l|}{$\alpha-G p d$} \\
\hline$(\mathrm{N})$ & 50 & 50 & 64 & 30 & 53 & 40 & 50 & 50 & 40 & 55 & 65 \\
\hline A & 1.00 & 1.00 & 0.77 & 1.00 & 0.77 & 1.00 & 0.98 & 0.99 & 1.00 & 0.93 & 1.00 \\
\hline B & 0 & 0 & 0.02 & 0 & 0 & 0 & 0.01 & 0 & 0 & 0.07 & 0 \\
\hline $\mathrm{C}$ & 0 & 0 & 0.21 & 0 & 0.23 & 0 & 0.01 & 0.01 & 0 & 0 & 0 \\
\hline \multicolumn{12}{|l|}{ Aco-2 } \\
\hline$(\mathrm{N})$ & 60 & 60 & 36 & 40 & 58 & 40 & 50 & 50 & 40 & 30 & 30 \\
\hline A & 1.00 & 1.00 & 1.00 & 0.99 & 1.00 & 1.00 & 1.00 & 1.00 & 1.00 & 1.00 & 1.00 \\
\hline B & 0 & 0 & 0 & 0.01 & 0 & 0 & 0 & 0 & 0 & 0 & 0 \\
\hline \multicolumn{12}{|l|}{ Tre } \\
\hline$(\mathrm{N})$ & 45 & 35 & 52 & 45 & 71 & 50 & 40 & 50 & 50 & 45 & 45 \\
\hline A & 1.00 & 1.00 & 0.88 & 1.00 & 0.99 & 1.00 & 1.00 & 1.00 & 1.00 & 1.00 & 0.98 \\
\hline B & 0 & 0 & 0.10 & 0 & 0.01 & 0 & 0 & 0 & 0 & 0 & 0.02 \\
\hline C & 0 & 0 & 0.03 & 0 & 0 & 0 & 0 & 0 & 0 & 0 & 0 \\
\hline
\end{tabular}

Cluster analysis was conducted on a matrix of $D$ values for all pairwise comparisons among all populations by the unweighted pair group algorithms using arithmetic averages of Sneath and Sokal. ${ }^{36}$ The resulting dendrogram (Figure 2) shows that populations from the Amazon region (Salvaterra, Camará, Bacabal, and Santarem) and populations from the tropical east coast (Fortaleza, Sobral, Itapipoca, and Baturité) clustered together below the 0.01 level. Populations from the
Brazilian plateau (Jacobina, Lapinha Caves, and Montes Claros) clustered together below the 0.02 level. Genetic differentiation for all populations was below 0.03, suggesting that all populations were very similar genetically. These values are consistent with local populations within a single species.

To estimate genetic differentiation among populations from different climatic regions, we arranged populations in a hierarchy based on region. Variance of allele frequencies

TABLE 3

Genetic variability of populations of Lutzomyia longipalpis from Brazil at 16 isozyme loci (standard errors in parentheses)

\begin{tabular}{|c|c|c|c|c|c|}
\hline \multirow[b]{2}{*}{ Population } & \multirow{2}{*}{$\begin{array}{c}\text { Mean } \\
\text { sample size } \\
\text { per locus }\end{array}$} & \multirow{2}{*}{$\begin{array}{c}\text { Mean } \\
\text { no. of alleles } \\
\text { per locus }\end{array}$} & \multirow{2}{*}{$\begin{array}{c}\text { Percentage } \\
\text { of loci } \\
\text { polymorphic* }\end{array}$} & \multicolumn{2}{|c|}{ Mean heterozygosity } \\
\hline & & & & Direct count & $\begin{array}{c}\text { Hardy-Weinberg } \\
\text { expected } \dagger\end{array}$ \\
\hline 1. Salvaterra & $57.0(3.4)$ & $1.8(0.3)$ & 18.8 & $0.033(0.02)$ & $0.045(0.02)$ \\
\hline 2. Camará & $56.3(4.0)$ & $1.7(0.2)$ & 18.8 & $0.049(0.03)$ & $0.061(0.03)$ \\
\hline 3. Bacabal & $56.1(2.2)$ & $1.8(0.2)$ & 6.3 & $0.044(0.03)$ & $0.052(0.03)$ \\
\hline 4. Santarem & $56.3(3.9)$ & $2.2(0.4)$ & 25.0 & $0.093(0.04)$ & $0.124(0.05)$ \\
\hline 5. Forteleza & $57.1(2.9)$ & $2.1(0.3)$ & 25.0 & $0.073(0.03)$ & $0.082(0.03)$ \\
\hline 6. Baturité & $48.5(2.0)$ & $1.9(0.3)$ & 37.5 & $0.084(0.04)$ & $0.111(0.04)$ \\
\hline 7. Itapipoca & $55.1(3.4)$ & $1.8(0.3)$ & 25.0 & $0.065(0.03)$ & $0.089(0.04)$ \\
\hline 8. Sobral & $57.9(3.9)$ & $2.2(0.3)$ & 25.0 & $0.069(0.03)$ & $0.098(0.04)$ \\
\hline 9. Jacobina & $58.8(3.0)$ & $2.6(0.5)$ & 31.3 & $0.066(0.03)$ & $0.117(0.05)$ \\
\hline 10. Montes Claros & $57.4(4.4)$ & $2.2(0.4)$ & 43.8 & $0.121(0.04)$ & $0.124(0.04)$ \\
\hline 11. Lapinha & $55.4(3.2)$ & $2.4(0.3)$ & 50.0 & $0.100(0.03)$ & $0.163(0.04)$ \\
\hline
\end{tabular}

* A locus is considered polymorphic if the frequency of the most common allele does not exceed 0.95.

$\dagger$ Unbiased estimate $\left(\right.$ see $\mathrm{Nei}^{35}$ ). 
TABLE 4

Variance in allele frequencies among populations of Lutzomyia longipalpis partitioned into variance among climatic regions and among populations within climatic regions; variance components are combined among loci

\begin{tabular}{lllll}
\hline \multicolumn{1}{c}{ Source } & Variance & $\begin{array}{l}\% \text { Total } \\
\text { variance }\end{array}$ & \multicolumn{1}{c}{$\mathrm{F}_{\mathrm{ST}}$} & \multicolumn{1}{c}{$\mathrm{Nm}$} \\
\hline Populations within & & & & \\
$\quad$ climatic regions & 0.089 & $62.6 \%$ & 0.054 & 4.38 \\
Among climatic regions & 0.053 & $37.4 \%$ & 0.031 & 7.81 \\
Among all populations & 0.14228 & & 0.084 & 2.73 \\
\hline
\end{tabular}

among all loci was quantified using Wright's F statistic. Table 4 shows that $62.6 \%$ of the total variance among all populations was attributed to differences among sampling locations within climatic regions. The variance in allele frequencies among climatic regions was $37.4 \%$, which was almost half of the within region variance. The $N_{e} m$ estimates among climatic regions (7.81) was almost twice as high as that within regions ${ }^{24,37}$ (Table 4), indicating higher gene flow among climatic region than within regions.

Morphologic examination. Individual males from 9 populations were examined under a stereomicroscope for the presence of pale spots on the third and fourth abdominal tergites. The aim was to estimate proportions of the two abdominal spot forms (one and two spots) described by Mangabeira in 1969. ${ }^{3}$ Populations from Santarem, Salvaterra, Camará, Bacabal, and Montes Claros consisted entirely of males with one pair of spots on the fourth abdominal tergite. Male flies from Jacobina all had two pairs of abdominal spots, one on the third and the other on the fourth abdominal tergite. However, male flies from Fortaleza, Baturité, Sobral, and Itapipoca (all in the state of Ceará) were of three types: one spot, two spot, and an intermediate form with a small spot on the third tergite. We adopted a genetic model described by Mukhopadhyay and others ${ }^{20}$ They assumed that the spot on the third tergite is controlled by a single gene with three phenotypes: no spot, spot, and intermediate size spot (heterozygotes). We then tested the third tergite phenotypes for compliance to $\mathrm{H}-\mathrm{W}$ expectations. Male flies from Fortaleza and Baturité were in close agreement to H-W equilibrium. In Fortaleza, the expected morphologic frequencies were 1 -spot $=26.18$, no spot $=1.18$, and intermediates $=11.64$, and $p_{1-\text { spot }}=0.82, q_{\text {no spot }}=0.18$ $\left(\chi^{2}=0.41, P<0.84\right)$. In Baturité, the expected frequencies

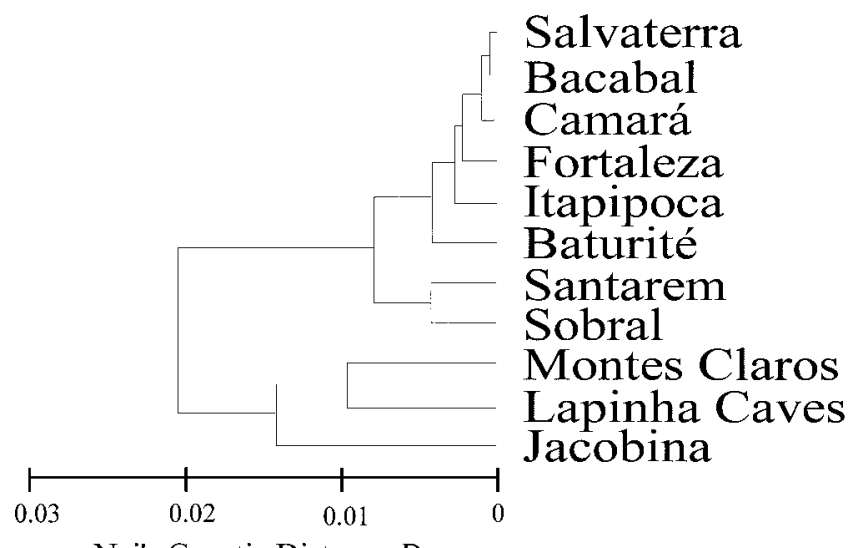

Nei's Genetic Distance $D$

FIGURE 2. Dendrogram constructed from values for $D$ for field populations of Lutzomyia longipalpis collected in Brazil.

were 1 -spot $=81.42$, no spot $=0.42$, and intermediates $=$ 12.17 , and $p_{1-\text { spot }}=0.94, q_{\text {no spot }}=0.07\left(\chi^{2}=6.86, P<\right.$ 0.009). Extreme deviation from $\mathrm{H}-\mathrm{W}$ equilibrium were observed in Sobral and Itapipoca. In Sobral, the expected frequencies were 1 -spot $=2.45$, no spot $=144.45$, and intermediates $=38.11$, and $p_{1-\text { spot }}=0.12, q_{\text {no spot }}=0.88\left(\chi^{2}=\right.$ 125.91, $P<0.001)$. In Itapipoca, the expected frequencies were 1 -spot $=34.66$, no spot $=1.66$, and intermediates $=$ 15.68 , and $p_{1-\text { spot }}=0.82, q_{\text {no spot }}=0.18\left(\chi^{2}=47.74, P<\right.$ $0.001)$. Genotypic frequencies are presented in Table 5.

\section{DISCUSSION}

We observed heterozygosities ranging from $4.5 \%$ to $16.3 \%$ among the 11 populations studied. Some were higher and some lower than those expected for a typical insect, $7.8 \%\left(\mathrm{Nevo}^{38}\right)$, but all were within the ranges of values previously reported for $\mathrm{Lu}$. longipalpis. Bonnefoy and others ${ }^{25}$ reported a very low heterozygosity of 3.6-3.7\% within a single population of Lu. longipalpis sampled in different seasons in the Yungas of Bolivia. Lanzaro and others ${ }^{1}$ surveyed three laboratory strains and reported an overall heterozygosity of $5.7 \%$. A similar range of heterozygosities (5.1-5.4\%) was reported by Munstermann and others ${ }^{27}$ among 5 field populations in central Colombia. Mukhopadhyay and others $^{39}$ reported heterozygosity ranging from $3.9 \%$ to $10.7 \%$ among 5 laboratory strains. They also reported very high

TABLE 5

Numbers and percentages (in parentheses) of different male morphologic forms (1 spot, no spot) found in different populations of Lutzomyia longipalpis in Brazil*

\begin{tabular}{|c|c|c|c|c|c|}
\hline \multirow[b]{2}{*}{ Population } & \multirow[b]{2}{*}{ State } & \multirow[b]{2}{*}{ Number examined } & \multicolumn{3}{|c|}{ Male morphology } \\
\hline & & & $1 \mathrm{spot}$ & No spot & Intermediate \\
\hline Fortaleza & Ceará & 39 & $26(66.7)$ & $1(2.6)$ & $12(30.7)$ \\
\hline Baturité & Ceará & 94 & $83(88.3)$ & $2(2.1)$ & $9(9.6)$ \\
\hline Sobral & Ceará & 185 & $18(9.7)$ & $160(86.5)$ & $7(3.8)$ \\
\hline Itapipoca & Ceará & 52 & $42(80.8)$ & $9(17.3)$ & $1(1.9)$ \\
\hline Salvaterra & Pará & 100 & $0(0)$ & $100(100)$ & $0(0)$ \\
\hline Camará & Pará & 96 & $0(0)$ & $96(100)$ & $0(0)$ \\
\hline Santarem & Pará & 187 & $0(0)$ & $187(100)$ & $0(0)$ \\
\hline Jacobina & Bahia & 100 & $100(100)$ & $0(0)$ & $0(0)$ \\
\hline Montes Claros & Minas Gerias & 100 & $0(0)$ & $100(100)$ & $0(0)$ \\
\hline
\end{tabular}

* One spot have a prominent pale spot on the third abdominal tergite, no spot do not have one, and intermediates have a smaller spot. 
heterozygosity, $H=15.7 \%$, for a field population from Lapinha Caves in Brazil. In contrast, heterozygosity for the laboratory strain from the same site was $3.9 \%$. Dujardin and others $^{26}$ surveyed four field populations in Sud Yungas and Charcas, Bolivia and reported low heterozygosities ranging from $2.5 \%$ to $3.7 \%$. In our earlier studies, ${ }^{28}$ we reported heterozygosities ranging from $6.5 \%$ to $14.4 \%$ for three field populations from Colombia. We have also reported heterozygosities ranging from $2.2 \%$ to $6.5 \%$ for 11 field populations from three countries in Central America. ${ }^{29}$ Some of the variation in heterozygosity seen among the studies discussed above may be due to the number of enzyme loci sampled. Sample sizes of 20 or more loci are known to give more reliable estimates but most of the studies above involved 1016 loci.

In the present study, there was a trend towards low heterozygosities in sylvatic areas of the lower Amazon on Marajo Island, but moderate ones in semiarid rural areas of northeastern Brazil and high ones in peridomestic and urban areas of Jacobina, Montes Claros, Santarem and Lapinha Caves (near Belo Horizonte). Heterozygosity for the population from Lapinha Caves $(16.3 \%)$ was very similar to the value of $15.7 \%$ reported for the same population by Mukhopadhyay and others. ${ }^{39}$

Genotypic frequencies for all populations in the present study were in close agreement to $\mathrm{H}-\mathrm{W}$ expectations, suggesting that these represent single populations composed of individuals with random mating. This was especially significant for the population from Sobral, where reproductive isolation has been reported between two morphologic forms: one spot and two spots. ${ }^{3}$ In the present study, we examined male morphology to ensure that both morphologic forms were included in our collection, and to determine the proportion of each form in the total collection. The results (Table 5) show that the one spot phenotype made up $86.5 \%$ of collections from Sobral and the two spots only about $10 \%$. The occurrence of intermediate forms $(3.8 \%)$ suggests that there was mating between the two. Although the abdominal spot phenotypes at Sobral are clearly not in $\mathrm{H}-\mathrm{W}$ equilibrium (assuming that this character is controlled by a single gene), there was no evidence of assortative mating from the isozyme data. This suggests that the spot phenotype is polygenic and/or that there is a large environmental component to this phenotype. Previous studies ${ }^{3,20}$ have made it clear that the two morphologic forms are not maintained by reproductive isolation between forms. This observation is supported by this study.

Analysis for compliance with $\mathrm{H}-\mathrm{W}$ equilibrium for data pooled from all populations suggested some degree of genetic substructuring. Earlier studies ${ }^{40}$ showed that the flight range of adult Lu. longipalpis is limited, usually not more than 300 meters. Considering the physical distance among the populations sampled, isolation by distance may account for the observed genetic structuring. Estimates of effective migration rates $\left(N_{e} m\right)$ for all populations in this study were low (2.73). Estimates for $N_{e} m$ for three neighboring populations (10-60 km) on Marajo Island (Salvaterra, Bacabal, and Camará) 10-60 km apart was large (25.79), indicating that these populations are essentially panmictic. Similarly, $N_{e} m$ among populations in Ceará, which are within 200-700 $\mathrm{km}$ of each other, was 6.91 , which is higher than the overall
$N_{e} m$ (2.73), reinforcing the isolation by distance explanation. Similar observations were reported in central Colombia in which populations of $\mathrm{Lu}$. longipalpis in neighboring areas exhibited higher $N_{e} m$ values when compared with the total population. ${ }^{41}$ Alternatively, stabilizing selection at allozyme loci may explain the observed structure. An excellent example comes from the work of Karl and Avise. ${ }^{42}$ They used restriction fragment length polymorphism makers and found genetic discontinuity for the American oyster (Crassostrea virginica) between the Atlantic coast and the Gulf of Mexico, whereas earlier studies had reported uniformity in allozyme frequencies. ${ }^{42}$

The degree of genetic divergence among populations or taxa has traditionally been measured by estimating genetic distance. The statistic most often used is Nei's genetic distance $D$. Dujardin and others ${ }^{26}$ have correctly pointed out that Nei's genetic distances cannot be used to define species. However, Lanzaro and Warburg ${ }^{43}$ summarized Nei's genetic distances for populations within species and at various taxonomic levels and found a strong correlation between genetic distance and taxonomic classification of phlebotomine sand flies. The levels of genetic differentiation measured by Nei's genetic distance $(D)$ among the 11 populations in the present study were very low, less than 0.03 . These populations are very similar genetically and consistent with population within the same species. Cluster analysis (Figure 2) grouped populations from the Ceará and Pará below the 0.01 level of Nei's genetic distance, indicating that these populations are genetically indistinguishable.

Two types of evidence suggest the presence of more than one sibling species of Lu. longipalpis in Brazil: 1) reproductive isolation ${ }^{2,3}$ and 2) karyotype morphology and Gbanding. ${ }^{19}$ In the present study, we did not find evidence supporting the existence of more than a single species among the field populations of Lu. longipalpis we surveyed. None of the populations were fixed for alternative electromorphs at any locus. Deviations from $\mathrm{H}-\mathrm{W}$ equilibrium for pooled data can be explained by restriction in migration rates among populations or errors in sampling. Furthermore, the genetic distance we calculated $(D \sim 0.03)$ is consistent with populations within a single sand fly species. We intended to use genetic distance to provide clues in our effort to determine the taxonomic status of our study populations. This approach has previously been used to differentiate sibling species for other insect species, such as sibling species in the genus Anopheles. ${ }^{44-46}$

Acknowledgments: We thank Antonio Carlos Santos and Amaro Silva (FIOCRUZ, Salvador, Bahia, Brazil), Raimundo Nonato de Souza and Irineu Guerreiro de Souza (FIOCRUZ, Fortaleza, Brazil), Irolanda da Rocha Barata, Evaldo Carneiro das Chagas, and Lourdes Maria Garcez Silveira (Instituto Evandro Chagas, Belem, Brazil), and Claudio Meneses, Diamar C. Pinto, and all members of the Entomology Department of FIOCRUZ (Rio de Janeiro, Brazil) for field and technical assistance. We are greatly indebted to the authorities at FIOCRUZ in Salvador, Fortaleza, and Rio de Janeiro, as well as the Instituto Evandro Chagas (Belem, Brazil) for providing us with transportation. We are grateful to Francisco Freitas, Herberto Carvalho Dantas Filho, Leonidas Monte Batista, Manoel Caetano Duarte, and Osvaldo Carlos Silva da Silveira for field assistance in Santarem. We also thank Paulo Calaça and Evangley Rios for field assistance in Montes Claros. Lastly, we thank Bill Sweeney and Scott Marriott (University of Texas Medical Branch, Galveston, TX) for technical support. 
Financial support: This research was supported, in part, by a grant from the John D. and Catherine T. MacArthur Foundation program entitled "Molecular Biology of Parasite Vectors", by grant AI39540 from the National Institutes of Health to Gregory C. Lanzaro, and by funds from Conselho Nacional de Desenvolvimento Cientifico e Technologico and Fundação Nacional de Saude to Bruce Alexander.

Authors' addresses: John-Paul Mutebi and Gregory C. Lanzaro, Center for Tropical Diseases, Department of Pathology, University of Texas Medical Branch, Galveston, TX 77555-0609. Bruce Alexander, Departmento de Parasitologia, Instituto de Ciências Biológicas, Universidade Federal de Minas Gerais, Belo Horizonte, Minas Gerais, Brazil. Italo Sherlock, Centro de Pesquisas Gonçalo MonizFIOCRUZ, Salvador, Bahia, Brazil. Jose Wellington, Núcleo de Medicina Tropical, Universidade Federal do Ceará, Fortaleza, Ceará, Brazil. Adelson A. Souza, Seção de Parasitologia, Instituto Evandro Chagas, Fundação Serviços Pública, Belém, Pará, Brazil. Jeffrey Shaw, Departamento de Parasitologia, Instituto de Ciências Biomédicas, Universidade de São Paulo, São Paulo, São Paulo, Brazil. Elizabeth F. Rangel, Departmento de Entomologia, Instituto Oswaldo Cruz, Rio de Janeiro, Brazil

\section{REFERENCES}

1. Lanzaro GC, Ostrovska K, Herrero MV, Lawyer PG, Warburg A, 1993. Lutzomyia longipalpis is a species complex: genetic divergence and interspecific hybrid sterility among three populations. Am J Trop Med Hyg 48: 839-847.

2. Ward RD, Ribeiro AL, Ready AD, Murtagh A, 1983. Reproductive isolation between different forms of Lutzomyia longipalpis (Lutz \& Neiva) and its significance to kala-azar distribution in South America. Mem Inst Oswaldo Cruz. 78: 269280.

3. Ward RD, Phillips A, Burnet B, Marcondes CB, 1988. The Lutzomyia longipalpis complex: reproduction and distribution. Service MW, ed. Biosystematics of Haematophagous Insects. Oxford: Clarendon, 257-269.

4. Corredor A, Gallego, JF, Tesh RB, Morales A, Ferro C, Young DG, Kreutzer RD, Boshell J, Palau MT, Caceres E, Palaez D, 1989. Epidemiology of visceral leishmaniasis in Colombia. Am J Trop Med Hyg 40: 480-486.

5. Lainson J, Shaw JJ, Ryan L, Silveira FT, Fraiha H, 1983. Leishmaniasis in Brazil. XIX. Visceral leishmaniasis in the Amazon region, and the presence of Lutzomyia longipalpis on the island of Marajó, Pará State. Trans $R$ Soc Trop Med Hyg 77: 323-330.

6. Young DG, Lawyer PG, 1987. New World vectors of the leishmaniases. Harris KF, ed. Current Topics in Vector Research. New York: Springer-Verlag, 29-71.

7. Young DG, Duncan MA, 1994. Guide to the Identification and Geographic Distribution of Lutzomyia Sand Flies in Mexico, the West Indies, Central and South America (Diptera: Psychodidae). Gainesville, FL: Associated Publishers.

8. Grimaldi G, Tesh RB, McMahon-Pratt D, 1989. A review of geographic distribution and epidemiology of leishmaniasis in the New World. Am J Trop Med Hyg 40: 687-725.

9. Arias JR, Monteiro PS, Zicker F, 1996. Re-emergence of visceral leishmaniasis in Brazil. Emerg Infect Dis 2: 145-146.

10. Eduardo de Alencar J, 1962. Kala-azar in Brazil. Sci Rep Ist Super Sanitá 2: 116-123.

11. Viera JB, Lacerda MM, Marsden PD, 1990. National reporting of leishmaniasis: the Brazilian experience. Parasitol Today 6: 339-340.

12. Deane LM, Grimaldi Jr G, 1985. Leishmaniasis in Brazil. Chang K-P, Brays RS, eds. Leishmaniasis. Volume 1. Amsterdam: Elsevier, 247-281.

13. Lainson R, Shaw JJ, Ryan L, Ribeiro RSM, Silveira FT, 1985. Leishmaniasis in Brazil. Visceral leishmaniasis in the Amazon region and further observations on the role of Lutzomyia longipalpis as the vector. Trans $R$ Soc Trop Med Hyg 79: 223226.

14. Sherlock IA, 1996. Ecological interactions of visceral leishman- iasis in the state of Bahia, Brazil. Mem Inst Oswaldo Cruz 91: 671-683.

15. Momen H, 1997. Second national meeting on strategic research in leishmaniasis. Mem Inst Oswaldo Cruz 90: 775-776.

16. Jeronimo SMB, Oliviera RM, Mackay S, Costa RM, Sweet J, Nascimento ET, Luz KG, Fernandes MZ, Jernigan J, Pearson RD, 1994. An outbreak of visceral leishmaniasis in Natal, Brazil. Trans $R$ Soc Trop Med Hyg 88: 386-388.

17. Lane R, Phillips A, Molyneux DH, Procter G, Ward RD, 1985. Chemical analysis of the abdominal glands of two forms of Lutzomyia longipalpis: site of a possible sex pheromone? Ann Trop Med Parasitol 81: 311-317.

18. Phillips A, Ward RD, Ryan L, Molyneux DH, Laison R, Shaw JJ, 1986. Chemical analysis of compounds extracted from the "tergal" spots of Lutzomyia longipalpis from Brazil. Acta Trop 43: 271-276.

19. Yin H, Mutebi J-P, Marriott S, Lanzaro GC, 1998. Metaphase karyotypes and chromosome G-banding in members of the Lutzomyia longipalpis species complex. Med Vet Entomol 13: 72-77.

20. Mukhopadhyay J, Ghosh K, Azevedo ACR, Rangel EF, Munstermann LE, 1998. Genetic polymorphism in morphological and biochemical characters of Brazilian Lutzomyia longipalpis (Diptera: Psychodidae). J Am Mosq Control Assoc 14: 277282.

21. Caillard T, Tibayrene M, Dujardin J-P, Desjeux P, 1985. Distinction by means of isozymes between two cryptic species within the taxon Psychodopygus carrerai (Diptera: Psychodidae). CR Acad Sci Paris 300: 479-481.

22. Rogo LM, Khamala CPM, Mutinga MJ, 1988. Biochemical identification of Phlebotomus (Larroussius) pedifer and Phlebotomus (Larroussius) elegonensis. Biochem Syst Ecol 16: 655-659.

23. Kreutzer RD, Palau MT, Morales A, Ferro C, Feliciangeli D, Young DG, 1990. Genetic relationships among phlebotomine sand flies (Diptera: Psychodidae) in the verrucarum species group. J Med Entomol 27: 1-8.

24. Perrotti E, La Rosa G, Maroli M, Pozio E, 1991. Electrophoretic studies on two Phlebotomus species (Diptera: Psychodidae) from Italy. Parassitologia 33 (suppl 1): 463-469.

25. Bonnefoy S, Tibayrenc M, Le Pont F, Dujardin J-P, Desjeux P, Ayala FJ, 1986. An isozymic study of Lutzomyia longipalpis (Diptera, Psychodidae), the vector of visceral leishmaniasis in the "Yungas" (Bolivia). Cah ORSTOM Ser Entomol Parasitol 24: 213-217.

26. Dujardin J-P, Torrez EM, Le Pont F, Hervas D, Sossa D, 1997. Isozymic and metric variation in the Lutzomyia longipalpis complex. Med Vet Entomol 11: 394-400.

27. Munstermann LE, Morrison AC, Ferro C, Pardo R, Torres M, 1998. Genetic structure of local populations of Lutzomyia longipalpis (Diptera: Psychodidae) in Colombia. J Med Entomol 35: 82-89.

28. Lanzaro GC, Alexander B, Mutebi JP, Montoya-Lerma J, Warburg A, 1998. Genetic variation among laboratory colony populations of Lutzomyia longipalpis (Lutz \& Neiva, 1912) (Diptera: Psychodidae) from Colombia. Mem Inst Oswaldo Cruz 93: 65-69.

29. Mutebi J-P, Rowton E, Herrero MV, Ponce C, Belli A, Valle S, Lanzaro GC, 1998. Genetic variability among populations of the sand fly Lutzomyia (Lutzomyia) longipalpis (Diptera: Psychodidae) from Central America. J Med Entomol 35: 169174.

30. Selander RK, Smith MH, Yang SY, Johnson WE, Gentry JB, 1971. Biochemical polymorphism and systematics in the genus Peromyscus. I. Variation in the old-field mouse (Peromyscus polionotus). Univ Texas Publication 7103: 49-90.

31. Clayton JW, Tretiak DN, 1972. Amine-citrate buffers for $\mathrm{pH}$ control in starch gel electrophoresis. J Fish Res Board Can 29: 1169-1172.

32. Ayala FJ, Powell JR, 1972. Allozymes as diagnostic characters of sibling species of Drosophila. Proc Natl Acad Sci USA 69: 1094-1096.

33. Swofford DL, Selander RB, 1989. BIOSYS-1. A Computer Program for the Analysis of Allelic Variation in Population Ge- 
netics and Biochemical Systematics. Urbana, IL: Illinois Natural History Survey.

34. Wright S, 1931. Evolution in Mendelian populations. Genetics 16: $97-159$

35. Nei M, 1978. Estimation of average heterozygosity and genetic distance from a small number of individuals. Genetics 89: 583-590.

36. Sneath PHA, Sokal RR, 1973. Numerical Taxonomy. San Francisco: W. H. Freeman.

37. Ayala FJ, 1975. Genetic differentiation during the speciation process. Evol Biol 8: 1-78.

38. Nevo E, 1978. Genetic variation in natural populations: patterns and theory. Theor Popul Biol 13: 121-117.

39. Mukhopadhyay J, Rangel EF, Ghosh K, Munstermann LE, 1997. Patterns of genetic variability in colonized strains of Lutzomyia longipalpis (Diptera: Psychodidae) and its consequences. Am J Trop Med Hyg 57: 216-221.

40. Morrison AC, Ferro C, Morales A, Tesh RB, Wilson ML, 1994. Dispersal of the sand fly Lutzomyia longipalpis (Diptera: Psychodidae) at an endemic focus of visceral leishmaniasis in Colombia. J Med Entomol 30: 427-435.
41. Munstermann LE, Morrison AC, Ferro C, Pardo R, Torres M, 1998. Genetic structure of local populations of Lutzomyia longipalpis (Diptera: Psychodidae) in Colombia. J Med Entomol 35: 82-89.

42. Karl SA, Avise JC, 1992. Balancing selection at allozyme loci in oyster: implications from nuclear RFLPs. Science 256 : $100-102$.

43. Lanzaro GC, Warburg A, 1995. Genetic variability in phlebotomine sandflies: possible implications for leishmaniasis epidemiology. Parasitol Today 11: 151-154.

44. Bullini L, Colluzzi M, 1982. Evolutionary and taxonomic inferences of electrophoretic studies in mosquitoes, Steiner WWM, Tabachnick WJ, Rai KS, Narang S, eds. Recent Developments in the Genetics of Insect Disease Vectors. Champaign, IL: Stipes, 465-482.

45. Lambert DM, 1983. A population genetical study of the African mosquito Anopheles marshallii (Theobald). Evolution 87: 484-495.

46. Lanzaro GC, Narang SK, Seawright JA, 1990. Speciation in an anopheline (Diptera: Culicidae) mosquito: enzyme polymorphism and genetic structure of populations. Ann Entomol Soc Am 83: 578-585. 